a dearth of newspapers and light 1 terature. The After-Care Association still does excellent work in providing homes and procuring work for friendless women patients on discharge, and it is stated that a similar society for the assistance of men is very much needed.

The combined rate of mortality upon the total average number resident appears to be between 9 and 10 per cent. In an appendix attached to the report is a table showing the station or occupation of patients admitted during the year 1891 . Labourers seem to be the most numerous patients, of whom 154 were admitted during 1891 ; those having no occupation produced 54 patients ; clerks contribinted 49 , tinplate workers 30 , porters 25 , shoemakers 25 , and painters 24 . The annual cost of maintenance of the asylums is $£ 357,464$.

\section{ASSOCIATION INTELLIGENCE}

\section{BRANCH MEETINGS TO BE HEI D.}

Metropolitan Counties :Branch: Hertfordshire District.-A meetiog of the above Branch will take place at the Town Hall, st. Albans, on Friday, November 11 th, at 6 P.M., Dr. Pavy, President of the kranch. in the chair. Election of officers for the year. Dr. Seymour Taylor will read a paper on Some of the Commoner Forms of Anæmia. Possibly other business. Members and their friends wishing to stay to dinner afterwards are requested to signify the same not later than November 7th, to the Honorary Secretary, H. L. BATEs, St. Albans.

SodTh-EAstern Branch : Wes r Kent District.-The'next meeting of this District will be held at St. Bartholomew's Hospital, Chatham, on Tuesday, November 8th, at 4 P.M. Dr. Franklyn Brown, of Rochester, in the chair. Communications, etc.: To receive Report from Medico Ethical Committee on the subject of Medical Tariff. Dr. Tannahill : (1) Clinical Notes on Colour Blindness; (2) On Lupus, and its Treatment by Koch's Method. Dr. J. V. Bell: A Case of Abdominal Section for Acut Intestinal Obstruction. Mr. P. Selby: On the Absorption of Pleura Effusion by Salicylate of Soda. Dr. A. Packman: Notes on a Case o Strangulated Inguinal Hernia: Operation with Radical Cure. Mr. T. F. Hugh Smith : Hydrothorax a Sequel of Influenza. The dinner will tak place at the Bull Hotel, Rochester, at 6.30 P M. Charge 6s. 6d., exclusive of wine. Gentlemen who intend to dine are particularly requested to signify their intention to the Chairman, Dr. Franklyn Brown, High Street Rochester, not later than Monday, November 7 th. All members of th South-Eastern Branch are entitled to attend this meeting, and to introduce professional friends.-E. GROUND, Deputy Honorary Secretary of the District. LANCASBIRE AND CHFSHIRE BRANCH.-The autumn meeting of this
Branch will be held in the Town Hall, Preston, about the last week in November. Gentlemen wishing to read papers or communications, or show cases, are requested to write to Dr. Glascott, 23, St. John Street, Manchester, as soon as possible.-C. E. GLASCOTT, M.D., JAS. BARB, M.D. Joint Honorary Secretaries.

Perthshire Branch - The winter meeting of this Branch will be held in the Station Hotel, Perth, on Friday, November 4th, at 4 P.M. Business : Election of office-bearers; report of Council ; report of treasurer; report of representative members; fix place of summer meeting; the President's address; exhibition of microscnpic slides illustrating recent work in cerebral pathology. A meeting of Council will be held at 3.15 P.M. After the meeting dinner will be served in the hotel, at $3 \mathrm{~s} .6 \mathrm{~d}$. each, in time to permit members leaving for the country by the evening trains.-A. R. URQUHART, Honorary Secretary.

SouTh of TRELAND BRANCH. - The annual meeting of this Branch will be held in the School of Art, Nelson Place, Cork, on Saturday, November 5th, at 4 P M. - PHILliP G. LEE, Honorary Secretary, 25, Yatrick's Hill, Cork.

ERRATUM.-In the report of the meeting of the Dorset and West Hants Branch, in the BRITISH MEDICAL JOURNAL of October 22 nd, p. 919 , line 27 for Dr. Peter James Duncan read Dr. Percy James Duncan.

SOUTHERN BRANCH: ISLE OF WIGHT DISTRICT. THe quarterly meeting of this District was held at the Rnyal National Hospital for Consumption, Ventinor, on October 27 th B. BARrow, F.R.C.S., President, in the chair. There was an unusually large attendance of members.

Next Meeting.- It was decided that the January meeting of the District should be held at Sandown.

Communications.-Dr. WiLliamson read an account of a unique case, with notes of the post-mortem examination. The patient had suffered from Uterine Fibroids, Pelvic Sarcoma, and Cystic Disease of Both Ovaries. A brief discussion followed. -Dr. Sinclair CoghrLl gave an account of the later progress of the cases treated with Tuberculin at the hospital, and presented for examination the patient in whom the disease had been most advanced and extensive at the time of inoculation. One of the ten cases had been lost sight of. Of the remaining nine, only one had manifested a tendency to further decline in health, the others all being in better health than before inoculation. Dr. RoBerson mentioned that his own experi- ence had been less favourable, but that recent experiments seemed to warrant a hope that a more reliable, beneficial product of bacillary growth than that of Koch might ultimately be discovered.-Mr. Woon read a short account of the treatment of Ingrowing Toenail by a small silver lever inserted under the edge of the nail, and showed a case of thirty years' standing which had been completely cured by use of the lever for three months. In the discussion which followed, Dr. BucK advocated the plan of cutting a nick one-eighth to one-quarter inch deep in the centre of the free edge of the nail. Mr. GreEn gave his experience of Martin's method of cutting away granulations and inserting a pledget of wool under the offending edge as very successful. Dr. Pletrts advocated very free removal of the granulation tissue along the whole ingrowing edge of the nail. All agreed with Mr. Wood as to the importance of the manner of trimming the nail in preventing recurrence.

BIRMINGHAM AND MIDLAND COUNTIES BRANCH.

TyE first ordinary meeting of the session was held in the Library of the Medical Institute, Birmingham, on Thursday, October 13th ; Dr. WADE in the chair. There were thirty-seven members present.

New Members. - The following were elected members of the Branch: Samuel Greenwood, Lozells, L.R.C.P. and S.Ed., L.S.A.; J. S. Reynolds, Wolverhampton, L.R.C.P. and S.Ed., L.F.P. and S.Glasg.

Congratulations to Sir Walter Foster.-On the motion of Dr. WADE, seconded by Dr. ThURSFIELD, and supported by Dr. DodgLAs, it was unanimously resolved: "That the hearty congratulations of this Branch be and are hereby tendered to Sir Walter Foster, M.D., M.P., Secretary to the Local Government Board, upon his promotion to ministerial office, so honourable alike to himself and to the profession he worthily represents.'

Papers and Cases.-Mr. BARLING read a paper on the Treatment of Perforated Gastric Ulcer. In the discussion which followed, Mr. Lloyd, Dr. Deanesly, Mr. May, Dr. Taylor, Dr. Simon, and Dr. Melson took part; and Mr. Barling replied.-Mr. Haslam showed a patient upon whom he had performed Total Extirpation of an Epitheliomatous Penis by Thiersch's Method.-Mr. V. JACKson showed a specimen of Loose Cartilage successfully removed from the knee joint of a man. It consisted of part of one of the articular cartilages which had been broken off from a bove end during an accidental sprain some few weeks before.-Mr. BARLING showed a girl upon whom he had successfully operated for Perforated Gastric Ulcer; and also a patient from whom he had successfully removed Multiple Intralaryngeal Papilloma by the operation of Thyrotomy.

\section{OXFORD AND DISTRICT BRANCH.}

A GENERAL meeting of this Branch was held on October 28th at the Radcliffe Infirmary, Oxford, Dr. BYwATER WARD, President, in the chair. Twenty-six members were present, and Dr. Handfield Jones was present as a visitor.

New M mber.-Dr. Gardiner, of Steeple Aston, was elected a member of the Branch.

Communications.-Mr. Bloxsom E read a paper on Bacteriology, and showed some beautiful microscopic specimens.Dr. Brooks showed a specimen of Cirrhotic Liver in a Child. -Dr. Yelf read notes of a case of Pelvic Abscess and Suppurating Fibroid. Dr. HANDFIELd Jones made remarks on the case and on the suppuration of fibroids.-Dr. Collier opened a discussion on Diphtheria and Allied Membranous Inflammations of the Throat. Dr. Pemberton, Mr. Winkfield, Mr. Bloxsome, Dr. Rice, Mr. Cheatle, and Dr. Moore took part in the discussion, which was adjourned.

GlasGow ObStetrical and Grnacological Societr.Officers for ensuing session :-Honorary President : Sir Spencer Wells, Bart. President: Rolsert Pollok, M.B. Senior VicePresident: G. A. Turner, M.D. Junior Vice-President: Thos. Richmond, L.R.C.P.E. Treasurer: Alex. Miller, L.R.C.P.E., etc. Secretary: J. Nigel Stark, M.B. Reporting Secretary: Robert Jardine, M.D. Pathologist : A. Milroy, M.D. Council: Rubert Kirk, M.D. ; H. St. Clair Grey, M.D.; Malcolm Black, M.D. ; E. H. L. Oliphant, M.D. ; A. Richmond, M. B. ; D. N. Knox, M.D. 